\title{
Intraguild predation in three generalist predatory mites of the family Phytoseiidae (Acari: Phytoseiidae)
}

\author{
Faten M. Momen * (D) and Amira Abdel-Khalek
}

\begin{abstract}
Background: The predatory mites, Neoseiulus californicus (McGregor), N. barkeri (Hughes), and Amblyseius swirskii Athias-Henriot, are important predators attacking many insect and mite pests. They can coexist in the same habitat and engage in intraguild predation (IGP).

Main body: IGP was assessed among the exotic one N. californicus and the native species N. barkeri and A. swirskii as Intraguild predator (IG-predator)/intraguild prey (IG-prey) in either absence or presence of extra-guild prey Tetranychus urticae Koch (EG-prey). In the laboratory, the physiological parameters, longevity, fecundity, and predation rate of these predatory mites' females, fed on EG-prey, were evaluated, where phytoseiid larvae are considered as (IG-prey) or combined IG-prey with EG-prey. All predatory species consumed larval stages of each other's, but in case of $\mathrm{N}$. californicus, females failed to sustain oviposition on N. barkeri larvae. Also, it was noticed that N. californicus females killed 3 times more A. swirskii larvae than N. barkeri larvae, whereas A. swirskii consumed more N. californicus than N. barkeri larvae, respectively. Neoseiulus californicus lived longer on T. urticae and A. swirskii larvae than on N. barkeri, while the latter survived longer on $T$. urticae only than on the other prey or with combinations with T. urticae. Amblyseius swirskii lived shorter when fed exclusively on T. urticae or IG-prey than on EG-prey combined with IG-prey. In choice experiments, N. californicus showed a higher preference to consume more T. urticae than any of phytoseiid larvae. The comparison between T. urticae and IG-prey diets definite the higher influence of T. urticae on the fecundity in N. californicus and N. barkeri than on IG-prey, whereas in A. swirskii fecundity was as equal on T. urticae as on IG-prey N. californicus larvae.
\end{abstract}

Conclusion: A. swirskii seemed to be the strongest IG-predator.

Keywords: Phytoseiid mites, Tetranychus urticae, Intraguild prey, Choice test

\section{Background}

Neoseiulus barkeri (Hughes), Amblyseius swirskii AthiasHenriot, and Neoseiulus californicus (McGregor) (Acari: Phytosiidae) are efficient control agents of the mite pest Tetranychus urticae (Koch) (Tetranychidae). Neoseiulus barkeri is considered as a generalist predatory mite (type III subtype e) which can feed on Frankliniella occidentalis (Pergande) (Ramakers and Van Lieburg 1982), Thrips tabaci Lind. (Bonde 1989), spider mites (Momen and El-

\footnotetext{
* Correspondence: fatmomen@yahoo.com

Pests and Plant Protection Department, National Research Centre (NRC), 31 El-Bouhoth Street, Dokki, Cairo 12311, Egypt
}

Borolossy 1999), stored product mites (Huang et al. 2013), and pollen grains (Addison et al. 2000). Amblyseius swirskii (type III subtype b) feeds usually on whitefly as well as spider, tarsonomid, and eriophyid mites, also thrips and pollen grains (Messelink et al. 2006; Momen 2009; Riahi et al. 2017), whereas N. californicus (the selective predator of tetranychid mites, type II) feeds on various species of the family Tetranychidae (McMurtry et al. 2013).

Maleknia et al. (2016) stated that in both greenhouse and outdoor conditions, $T$. urticae is an important pest of cucumber and it is necessary to be controlled by

\section{Springer Open}

(- The Author(s). 2021 Open Access This article is licensed under a Creative Commons Attribution 4.0 International License, which permits use, sharing, adaptation, distribution and reproduction in any medium or format, as long as you give appropriate credit to the original author(s) and the source, provide a link to the Creative Commons licence, and indicate if changes were made. The images or other third party material in this article are included in the article's Creative Commons licence, unless indicated otherwise in a credit line to the material. If material is not included in the article's Creative Commons licence and your intended use is not permitted by statutory regulation or exceeds the permitted use, you will need to obtain permission directly from the copyright holder. To view a copy of this licence, visit http://creativecommons.org/licenses/by/4.0/. 
predatory mites of the family Phytoseiidae. Intraguild predation (IGP) can occur when two or more predatory species sharing the same habitat and one species-being the intraguild predator (IG-predator) and the othersintraguild preys (IG-prey) and competing for the same prey (extra-guild prey (EG-prey) (Janssen et al. 2006; Momen and Abdel-Khalek 2009b). Some phytoseiid mites can kill and consume phytoseiid competitors when their natural or favorable mite/insect preys density is low (Ahmad et al. 2015). Discrimination between conspecific (the same predatory species) and heterospecific (another predatory species) individuals as (IG-prey) was known in some generalist phytoseiid mites (Schausberger 1999). Generalist phytoseiid mites (type III) preferred to predate on heterospecific to conspecific, although T. urticae was not reduced (Schausberger 1999). Ahmad et al. (2015) indicated that predation on heterospecific immature stage is the main aspect in IGP. In previous investigations, some traits of IGP in immatures and females predatory phytoseiid mites were investigated (Momen and Abdel-Khalek 2009a, b; Momen 2010; Ahmad et al. 2015). Amblyseius swirskii had higher predation rates on heterospecific prey Typhlodromus athiasae Porth and Swirski and Eusieus scutalis (AthiasHenriot) than on conspecific prey and all females failed to predate on eggs and protonymphs of its own (Momen and Abdel-Khalek 2009b). Also, A. swirskii was able to consume all stages (eggs, larvae, protonymphs, deutonymphs) of $N$. barkeri and P. persimilis Athias-Henriot (Maleknia et al. 2016). Neoseiulus barkeri females consumed more larvae and protonymphs of Typhlodrmous negevi Swirski and Amitai than its own (Momen 2010) and also attacked similar amounts of $A$. swirskii as $P$. persimilis (Maleknia et al. 2016). Neoseiulus californicus, Typhlodromips montdorensis (Schicha), and T. pyri (Scheuten) can feed on larval stages of each other and sustain oviposition (Hatherly et al. 2005). Both N. californicus and A. swirskii could serve as IG-predators and could develop on their IG-prey (Guo et al. 2016). Some factors may affect the strength of IGP and outcome of biological control and this primary is dependent on the predator species and ranges from harmful to harmless IG predators (Walzer and Schausberger 2013). These factors included predator aggressiveness, activity, and habitat characteristics (Walzer et al. 2004).

Because there was no previous study exists on IGP among $N$. barkeri, $N$. californicus, and A. swirskii in the absence or presence of T. urticae, the aim of the present study was to determine the interactions among the generalist predators in absence and presence of the EG-prey T. urticae. As well, the effect of different IG-prey in ovipositional period, longevity, predation rate, and fecundity of predatory mite females as IG-predators was investigated. Also, comparison of all the above parameters for IG-predators fed IG-prey with those obtained on mixed (IG-prey) with (EG-prey) T. urticae was done.

\section{Materials and methods \\ Mite rearing}

Initial culture of the two-spotted spider mite, T. urticae, was obtained from bean plants (Phaseolus vulgaris L.) grown in the field, at Giza Governorate, Egypt. It was maintained under the laboratory conditions of $25 \pm 1{ }^{\circ} \mathrm{C}$, $60 \pm 5 \% \mathrm{RH}$, and 16:8 h (L:D) photoperiod on acalypha plant Acalypha wilkesiana (Eupharbiaceae) as a wild plant in plastic trays. Fresh plants infested with T. urticae were placed in the trays weekly.

Neoseiulus barkeri and A. swirskii were obtained from cucumber plants (Cucumis sativus L.), grown in Fayoum Governorate, while $N$. californicus was collected from pepper in Giza Province. In the laboratory, they were reared on whole acalypha leaves that densely infested with $T$. urticae in a growth chamber at $28 \pm 2{ }^{\circ} \mathrm{C}, 75 \pm$ $5 \% \mathrm{RH}, 16: 8 \mathrm{~h}$ (L:D). New infested bean plants leaves were added to each predatory culture and the old ones were removed from each colony daily. The leaves were placed on water-saturated cotton pads in Petri dishes.

\section{Leaf disks}

Leaf disks, cut from leaflets collected from the middle part of acalypha plant, were placed in Petri dishes $(6 \mathrm{~cm}$ in diameter). Each plate was considered a replicate. The leaf disks (with $3.5 \mathrm{~cm}$ of diameter each) were placed on a water-saturated cotton pad in the Petri dishes in order to keep the leaves fresh. Water-saturated, absorbent cotton strip, $(1 \mathrm{~cm}$ wide), placed around the edge of the leaf disk, covered by a water-saturated cotton strip to prevent mites from escaping.

Newly emerged female of each species and one male were transferred onto rearing leaf disk with excess of food and left to mate. The male was removed, and the female transferred to fresh leaf disk and left $24 \mathrm{~h}$ without food to guarantee that all females had been starved for an equal period of time. Each experiment consisted of 24 mated females on individual disks supplied with a specific prey species.

\section{Intraguild predation test}

In the experiments, predatory mites' females were considered as (IG-predator), while larvae of heterospecifics species were considered as IG-prey (Montserrat et al. 2012).

The first set of experiments was female's predatory mite provided with only larval stages of its phytoseiid prey. Larval stage was selected because it is easy to handle and could be quickly selected once they had hatched. Larva was also a preferred stage for $N$. barkeri, A. 
swirskii, and N. californicus (Momen 2010). As a control, females of each predatory species were fed solely on $T$. urticae larvae.

\section{Choice test}

The second set of experiments was the choice test, which provided female mites of each predatory species with (50\% of $T$. urticae larvae and $50 \%$ of phytoseiid larva) as a food source.

Every $24 \mathrm{~h}$, the ovipositional period, ovipositional rate, the number of each food source consumed (determined by larval corpses), and female survival, was recorded. All excess food and corpses larvae on each disk were removed at each observation period and replaced with an identical amount of food as previously supplied. Dead and eaten larvae were removed from arenas and replaced daily. The shriveled corpses of the dead larvae were taken as evidence of predation. Observations were made daily and predatory females were checked until their death. In the preference test ( $T$. urticae and phytoseiid larvae), the number of $T$. urticae eaten compared with the number of phytoseiid larval prey consumed was determined.

\section{Statistical analysis}

One-way analysis of variance (ANOVA) (SPSS computer program) was conducted to evaluate the mean preoviposition and oviposition periods, longevity, mean total and daily number of eggs laid per female, mean total, and daily number of prey (IG-prey/EG-prey) consumed per female for each predator species kept on each of its prey sources.

Before the analyses, data were checked for normality. Data were fitted with the assumption of normality, not transformed, and means were compared by Tukey's $\operatorname{HSD}(P=0.05$ level $)$.

\section{Results and discussion}

Performance of Neoseiulus californicus (IG-predator) on Neoseiulus barkeri/Amblyseius swirskii (IG-prey) and Tetranychus urticae (EG-prey)

Neoseiulus californicus lived significantly longer when fed solely on $T$. urticae and $A$. swirskii than when fed on $A$. barkeri or on a mixed diet of $T$. urticae and phytoseiid prey $\left(F_{6,161}=85.70, P=0.0001\right)$. The mean ovipositional period of $N$. californicus females fed on combined diets (10 T. urticae $+10 \mathrm{~N}$. barkeri) performed shorter than those fed only on $A$. swirskii or T. urticae combined with other IG-prey. When $N$. californicus fed solely on $N$. barkeri larvae, females failed to sustain oviposition, while on $T$. urticae gave a higher fecundity rate than on A. swirskii or on a mixture of T. urticae and any other phytoseiid larvae $\left(F_{6,161}=3364, P=0.000\right)$ (Table 1$)$.
Prey type or number influenced the number of prey consumed by $N$. californicus. When $N$. californicus fed solely on EG-prey/IG-prey/combined prey, a significant difference was observed in its predation rate $\left(F_{6,161}=\right.$ 4009.60, 3017.76, $P=0.000)$. Neoseiulus californicus fed $N$. barkeri/A. swirskii larvae, its predation rate was significantly higher on the latter species (Table 1). Neoseiulus californicus consumed more T. urticae in total than those fed a mixed diet. It consumed significantly similar amount of IG-prey $N$. barkeri/A. swirskii, when combined with $T$. urticae (case of $20 \mathrm{~T}$. urticae + 20 IGprey). It was also noticed that providing of $T$. urticae significantly decreased the predation rate of IG-prey (Table 1). Neoseiulus californicus consumed up to $3.68,4.13$, and 2.93, 3.67 T. urticae for every $1 N$. barkeri and $A$. swirskii when fed on both prey sources. According to Lucas (2005), IGP can be unidirectional/bidirectional (mutual), the latter case when $2 / 3$ predator species prey on each other and each predator is also prey and vice versa. The present study proved that predation rates of the 3 tested predator species were bidirectional in absence or presence of $T$. urticae as EG-prey. Previous research has demonstrated that $N$. barkeri, $N$. californicus, and $A$. swirskii can serve as either prey or predators in intraguild predatory interactions among biological control agents (Maleknia et al. 2016; Haghani et al. 2019).

Females of $N$. californicus consumed IG-prey of $N$. barkeri and $A$. swirskii in non-choice experiments. Female's predator ate nearly 3 times more $A$. swirskii than $N$. barkeri. When T. urtice was combined, females of $N$. californicus fed on both T. urticae and both IG-prey with higher preference to T. urticae than phytoseiid larvae suggesting that the two-spotted spider mite is its preferred food. Resemble results were reported by Hatherly et al. (2005) who stated that when N. californicus offered a mixed diet of (phytoseiid larvae and T. urticae), it showed a marked preference for $T$. urticae. When $N$. californicus females were offered T. urticae combined with IG-prey, the IGP rate declined although the fecundity increased, except when fed on A. swirskii. This result is similar to those obtained by Meszaros et al. (2007) with Typhlodromus exhilarates Ragusa and T. phialatus Athias-Henriot and in general trends reported for the family Phytoseiidae (Schausberger 2003). The difference in IGP by $N$. californicus on $A$. swirskii and $N$. barkerii suggested that $N$. barkeri was unfavorable IG-prey to be fed and reproduce by $N$. californicus and could explain that both predators have differences in distribution in their habitat where $N$. californicus is more dominant on plants and always associated with tetranychid mites that producing heavy webbing; while $N$. barkeri living in soil/litter habitat while A. swirskii living on glabrous leaves (McMurtry et al. 2013). Moreover, $N$. californicus failed to sustain egg production when it was 
Table 1 Mean ( \pm SE) pre-oviposition, oviposition periods and longevity, mean number $( \pm$ SE) of total and daily eggs laid per female, total and daily number ( \pm SE) of prey consumed per female for Neoseiulus californicus fed solely on Tetranychus urticae (T.u.) or larval Neoseiulus barkeri (N.b.), Amblyseius swirskii (A.S.) or on a combination of T. urticae and larval phytoseiid

\begin{tabular}{|c|c|c|c|c|c|c|c|c|c|c|}
\hline \multirow[t]{3}{*}{$\begin{array}{l}\text { Prey and } \\
\text { number }\end{array}$} & \multicolumn{3}{|l|}{ Periods } & \multicolumn{2}{|c|}{$\begin{array}{l}\text { Eggs laid per } \\
\text { females }\end{array}$} & \multicolumn{4}{|c|}{ Consumption rates } & \multirow{3}{*}{$\begin{array}{l}\text { Ratio of } \\
\text { T. u: } \\
\text { predator } \\
\text { larvae } \\
\text { consumed }\end{array}$} \\
\hline & \multirow{2}{*}{$\begin{array}{l}\text { Pre- } \\
\text { oviposition }\end{array}$} & \multirow[t]{2}{*}{ Oviposition } & \multirow[t]{2}{*}{ Longevity } & \multirow{2}{*}{$\begin{array}{l}\text { Total } \\
\text { eggs }\end{array}$} & \multirow{2}{*}{$\begin{array}{l}\text { Daily } \\
\text { eggs }\end{array}$} & \multicolumn{2}{|c|}{ Total consumption } & \multicolumn{2}{|c|}{ Daily consumption } & \\
\hline & & & & & & T.u. & $\begin{array}{l}\text { Phytoseiid } \\
\text { larvae }\end{array}$ & T.u. & $\begin{array}{l}\text { Phytoseiid } \\
\text { larvae }\end{array}$ & \\
\hline 20T.u. & $\begin{array}{l}1.58 \pm 0.10 \\
b\end{array}$ & $\begin{array}{l}26.17 \pm 0.17 \\
a\end{array}$ & $\begin{array}{l}30.25 \pm \\
0.23 a\end{array}$ & $\begin{array}{l}37.50 \pm \\
0.23 a\end{array}$ & $\begin{array}{l}1.44 \pm \\
0.02 \mathrm{a}\end{array}$ & $\begin{array}{l}444.5 \pm \\
4.20 \mathrm{a}\end{array}$ & & $\begin{array}{l}14.69 \pm \\
0.05 a\end{array}$ & & \\
\hline 20 N.b. & $\begin{array}{l}0.00 \pm 0.00 \\
c\end{array}$ & $\begin{array}{l}0.00 \pm 0.00 \\
e\end{array}$ & $\begin{array}{l}23.50 \pm \\
0.25 e^{-}\end{array}$ & $\begin{array}{l}0.00 \pm \\
0.00 f\end{array}$ & $\begin{array}{l}0.00 \pm \\
0.00 \mathrm{e}\end{array}$ & & $\begin{array}{l}124.83 \pm 1.59 \\
b\end{array}$ & & $5.31 \pm 0.02 b$ & \\
\hline 20 A.s. & $\begin{array}{l}2.00 \pm 0.00 \\
a\end{array}$ & $\begin{array}{l}25.00 \pm 0.15 \\
b c\end{array}$ & $\begin{array}{l}29.58 \pm \\
0.20 \mathrm{ab}\end{array}$ & $\begin{array}{l}19.75 \pm \\
0.19 e^{-}\end{array}$ & $\begin{array}{l}0.79 \pm \\
0.01 \mathrm{~d}\end{array}$ & & $\begin{array}{l}363.92 \pm 2.04 \\
a\end{array}$ & & $12.30 \pm .02 \mathrm{a}$ & \\
\hline $\begin{array}{l}10 \text { T.u. }+10 \\
\text { N.b. }\end{array}$ & $\begin{array}{l}1.67 \pm 0.10 \\
a b\end{array}$ & $\begin{array}{l}23.42 \pm 0.22 \\
d\end{array}$ & $\begin{array}{l}27.58 \pm \\
0.28 d\end{array}$ & $\begin{array}{l}19.50 \pm \\
0.25 e^{-}\end{array}$ & $\begin{array}{l}0.83 \pm \\
0.01 d\end{array}$ & $\begin{array}{l}194.5 \pm \\
1.03 \mathrm{e}\end{array}$ & $53.25 \pm 0.88 \mathrm{e}$ & $\begin{array}{l}7.07 \pm \\
0.08 d\end{array}$ & $1.93 \pm 0.03 \mathrm{e}$ & $3.68: 1$ \\
\hline $\begin{array}{l}\text { 10 T.u. }+ \\
\text { 10A.s. }\end{array}$ & $\begin{array}{l}1.58 \pm 0.10 \\
b\end{array}$ & $\begin{array}{l}24.25 \pm 0.19 \\
c\end{array}$ & $\begin{array}{l}28.25 \pm \\
0.23 \mathrm{~cd}\end{array}$ & $\begin{array}{l}24.00 \pm \\
0.17 \mathrm{~d}\end{array}$ & $\begin{array}{l}0.99 \pm \\
0.01 c\end{array}$ & $\begin{array}{l}231.92 \pm \\
1.11 \mathrm{~d}\end{array}$ & $\begin{array}{l}79.25 \pm 0.68 \\
d\end{array}$ & $\begin{array}{l}8.22 \pm \\
0.70 c\end{array}$ & $2.81 \pm 0.01 \mathrm{~d}$ & $2.93: 1$ \\
\hline $\begin{array}{l}\text { 20T.u. }+20 \\
\text { N.b. }\end{array}$ & $\begin{array}{l}1.75 \pm 0.09 \\
a b\end{array}$ & $\begin{array}{l}25.58 \pm 0.25 \\
a b\end{array}$ & $\begin{array}{l}29.17 \pm \\
0.25 b c\end{array}$ & $\begin{array}{l}27.58 \pm \\
0.20 b\end{array}$ & $\begin{array}{l}1.08 \pm \\
0.01 b\end{array}$ & $\begin{array}{l}424.33 \pm \\
2.86 b\end{array}$ & $\begin{array}{l}103.08 \pm 1.32 \\
c\end{array}$ & $\begin{array}{l}14.57 \pm \\
0.15 a\end{array}$ & $3.53 \pm 0.02 c$ & 4.13:1 \\
\hline $\begin{array}{l}\text { 20 T.u. }+ \\
\text { 20A.s. }\end{array}$ & $\begin{array}{l}1.75 \pm 0.09 \\
a b\end{array}$ & $\begin{array}{l}25.33 \pm 0.25 \\
b\end{array}$ & $\begin{array}{l}28.67 \pm \\
0.25 b c\end{array}$ & $\begin{array}{l}26.67 \pm \\
0.23 c\end{array}$ & $\begin{array}{l}1.06 \pm \\
0.02 b\end{array}$ & $\begin{array}{l}379.58 \pm \\
5.81 \mathrm{c}\end{array}$ & $\begin{array}{l}107.67 \pm 4.67 \\
c\end{array}$ & $\begin{array}{l}13.23 \pm \\
0.14 b\end{array}$ & $3.75 \pm 0.15 c$ & $3.67: 1$ \\
\hline$F$ & 65.95 & 2463.95 & 85.70 & 3364.53 & 1548.31 & 4009.60 & 3017.31 & 5255.02 & 4384.79 & 853.77 \\
\hline$P$ & 0.000 & 0.000 & 0.000 & 0.000 & 0.000 & 0.000 & 0.000 & 0.000 & 0.000 & 0.000 \\
\hline
\end{tabular}

Where applicable, the ratio of $T$. urticae to larval phytoseiids consumed by adult females is given. Values in each column followed by the same letter are not significantly different $(P>0.05)$ when Neoseiulus californicus fed on $20 \mathrm{~T}$. urticae/phytoseiid larvae are compared to their other four prey combinations

fed IG-prey N. barkeri. On the contrary, Farazmand et al. (2015) indicated that $N$. californicus was able to sustain oviposition on IG prey. When the population of T. urticae is low and that could happen at the beginning and end of the cropping season, N. californicus may be able to feed and reproduce on IG-prey $A$. swirskii to maintain its population for a short time and certainly not on IG-prey $N$. barkeri since predation on that diet for survival only and not to producing offspring.

\section{Performance of Neoseiulus barkeri (IG-predator) on Neoseiulus californicus/Amblyseius swirskii (IG-prey) and Tetranychus urticae (EG-prey)}

The mean ovipositional period of $N$. barkeri females fed A. swirskii larvae was significantly longer than those fed $N$. californicus $\left(F_{6,161}=320.47, P=0.000\right)$. Neoseiulus barkeri survived significantly longer period when fed exclusively on $T$. urticae than when fed only on $N$. californicus/A. swirskii larvae/a mixed diet of $T$. urticae with phytoseiid larvae $\left(F_{6,161}=226.45, P=0.000\right)$ (Table 2).

When $N$. barkeri was fed solely on $N$. californicus/A. swirskii larvae, females laid statistically similar total eggs production, while on $T$. urticae solely showed a higher fecundity than on both IG-prey or on a mixture of $T$. urticae and phytoseiid larvae $\left(F_{6,161}=1529.19, P=\right.$ 0.000) (Table 2).

When $N$. barkeri fed solely on EG-prey/IG-prey/combined prey, a significant difference was observed in its predation rate $\left(F_{6,161}=7782.66,1512.10, P=0.000\right)$. Neoseiulus barkeri consumed more in total and daily number of $T$. urticae than those fed on a mixed diet (Table 2). The mean total number of $A$. swirskii larvae eaten by $N$. barkeri was statistically higher than that of $N$. californicus. Providing of T. urticae significantly decreased the predation of IG-prey (Table 2). Neoseiulus barkeri consumed up to 1.85 and $1.48 \mathrm{~T}$. urticae for every $1 \mathrm{~A}$. swirskii while that ratio was 0.96 ad $0.90 \mathrm{~T}$. urticae for every $1 N$. californicus when fed on both prey sources (Table 2).

Females of $N$. barkeri fed daily on similar amount of both IG-prey A. swirskii and N. californicus. When T. urticae was combined with IG-prey, females of N. barkerii fed on both prey with preference to $T$. urticae than IG-prey A. swirskii also to IG-prey $N$. californicus than T. urticae. IG-prey might comprise a less nutritive food for the IG-predator, especially in its oviposition period (Walzer and Schausberger 1999). Also, the daily number of IG-prey consumed by N. barkeri was lower (nearly half) than that of prey offered, suggesting that IGpredator response was affected by food quality (Ahmad et al. 2015). The total egg production of $N$. barkeri on both IG-prey was similar and relatively higher than those fed IG-prey combined with EG-prey. Walzer and Schausberger (1999), Hatherly et al. (2005), Momen and Abdel-Khalek (2009b), and Farazmand et al. (2015) indicated that predatory phytoseiids receive more nutritional 
Table 2 Mean ( \pm SE) pre-oviposition, oviposition periods and longevity, mean number $( \pm$ SE) of total and daily eggs laid per female, total and daily number ( \pm SE) of prey consumed per female for Neoseiulus barkeri fed solely on Tetranychus urticae (T.u.) or larval Neoseiulus californicus (N.c.), Amblyseius swirskii (A.S.) or on a combination of T. urticae, and larval phytoseiid

\begin{tabular}{|c|c|c|c|c|c|c|c|c|c|c|}
\hline \multirow{3}{*}{$\begin{array}{l}\text { Prey and } \\
\text { number }\end{array}$} & \multicolumn{3}{|l|}{ Periods } & \multicolumn{2}{|c|}{ Eggs laid per female } & \multicolumn{4}{|c|}{ Consumption rates } & \multirow{3}{*}{$\begin{array}{l}\text { Ratio of } \\
\text { T. u.: } \\
\text { predator } \\
\text { larvae } \\
\text { consumed }\end{array}$} \\
\hline & \multirow{2}{*}{$\begin{array}{l}\text { Pre- } \\
\text { oviposition }\end{array}$} & \multirow[t]{2}{*}{ Oviposition } & \multirow[t]{2}{*}{ Longevity } & \multirow[t]{2}{*}{ Total eggs } & \multirow{2}{*}{$\begin{array}{l}\text { Daily } \\
\text { eggs }\end{array}$} & \multicolumn{2}{|c|}{ Total consumption } & \multicolumn{2}{|c|}{ Daily consumption } & \\
\hline & & & & & & T.u. & $\begin{array}{l}\text { Phytoseiid } \\
\text { larvae }\end{array}$ & T.u. & $\begin{array}{l}\text { Phytoseiid } \\
\text { larvae }\end{array}$ & \\
\hline 20T.u. & $\begin{array}{l}1.50 \pm 0.10 \\
b\end{array}$ & $\begin{array}{l}26.50 \pm 0.23 \\
a\end{array}$ & $\begin{array}{l}30.50 \pm \\
0.28 \mathrm{a}\end{array}$ & $\begin{array}{l}36.00 \pm \\
0.28 \mathrm{a}\end{array}$ & $\begin{array}{l}1.36 \pm \\
0.01 \mathrm{a}\end{array}$ & $\begin{array}{l}478.33 \pm \\
3.65 \mathrm{a}\end{array}$ & & $\begin{array}{l}15.69 \pm \\
0.04 a\end{array}$ & & \\
\hline 20 N.c. & $\begin{array}{l}1.67 \pm 0.10 \\
a b\end{array}$ & $\begin{array}{l}18.50 \pm 0.23 \\
c\end{array}$ & $\begin{array}{l}22.42 \pm \\
0.29 c\end{array}$ & $\begin{array}{l}16.00 \pm \\
0.19 b c\end{array}$ & $\begin{array}{l}0.87 \pm \\
0.01 c\end{array}$ & & $\begin{array}{l}214.67 \pm 4.18 \\
b\end{array}$ & & $9.77 \pm 0.05 a$ & \\
\hline 20 A.s. & $\begin{array}{l}1.50 \pm 0.10 \\
b\end{array}$ & $\begin{array}{l}21.75 \pm 0.19 \\
b\end{array}$ & $\begin{array}{l}25.58 \pm \\
0.22 b\end{array}$ & $\begin{array}{l}16.75 \pm \\
0.21 b\end{array}$ & $\begin{array}{l}0.77 \pm \\
0.01 \mathrm{~d}\end{array}$ & & $\begin{array}{l}248.58 \pm 2.20 \\
a\end{array}$ & & $9.72 \pm 0.03 a$ & \\
\hline $\begin{array}{l}10 \text { T.u. }+ \\
10 \text { N.c. }\end{array}$ & $\begin{array}{l}1.58 \pm 0.10 \\
b\end{array}$ & $e^{16.25 \pm 0.19}$ & $\begin{array}{l}19.67 \pm \\
0.25 e^{-}\end{array}$ & $\begin{array}{l}10.75 \pm \\
0.19 e^{-}\end{array}$ & $\begin{array}{l}0.66 \pm \\
0.02 \mathrm{e}\end{array}$ & $\begin{array}{l}97.31 \pm \\
0.77 e^{-}\end{array}$ & $\begin{array}{l}101.58 \pm 1.06 \\
\text { e }\end{array}$ & $\begin{array}{l}4.96 \pm \\
0.05 \mathrm{e}\end{array}$ & $5.18 \pm 0.08 d$ & $0.96: 1$ \\
\hline $\begin{array}{l}\text { 10T.u. + } \\
\text { 10A.s. }\end{array}$ & $\begin{array}{l}2.00 \pm 0.00 \\
a\end{array}$ & $e^{15.92 \pm 0.18}$ & $\begin{array}{l}20.17 \pm \\
0.22 e^{-}\end{array}$ & $\begin{array}{l}10.67 \pm \\
0.25 e^{-}\end{array}$ & $\begin{array}{l}0.67 \pm \\
0.02 \mathrm{e}\end{array}$ & $\begin{array}{l}113.71 \pm \\
1.37 \mathrm{~d}\end{array}$ & $61.50 \pm 0.96 f$ & $\begin{array}{l}5.65 \pm \\
0.07 d\end{array}$ & $3.05 \pm 0.02 \mathrm{e}$ & $1.85: 1$ \\
\hline $\begin{array}{l}20 \text { T.u. }+ \\
20 \text { N.c. }\end{array}$ & $\begin{array}{l}1.75 \pm 0.09 \\
a b\end{array}$ & $e^{16.42 \pm 0.23}$ & $\begin{array}{l}20.50 \pm \\
0.26 \text { de }\end{array}$ & $\begin{array}{l}15.00 \pm \\
0.17 \mathrm{~d}\end{array}$ & $\begin{array}{l}0.92 \pm \\
0.01 \mathrm{~b}\end{array}$ & $\begin{array}{l}169.08 \pm \\
2.47 c\end{array}$ & $\begin{array}{l}188.42 \pm 2.70 \\
C\end{array}$ & $\begin{array}{l}8.25 \pm \\
0.07 c\end{array}$ & $9.19 \pm 0.03 b$ & $0.90: 1$ \\
\hline $\begin{array}{l}\text { 20 T.u. }+ \\
\text { 20A.s. }\end{array}$ & $\begin{array}{l}1.58 \pm 0.10 \\
b\end{array}$ & $\begin{array}{l}17.33 \pm 0.25 \\
d\end{array}$ & $\begin{array}{l}21.50 \pm \\
0.29 \mathrm{~cd}\end{array}$ & $\begin{array}{l}15.58 \pm \\
0.23 \mathrm{~cd}\end{array}$ & $\begin{array}{l}0.90 \pm \\
0.01 \mathrm{bc}\end{array}$ & $\begin{array}{l}234.52 \pm \\
1.66 b\end{array}$ & $\begin{array}{l}159.08 \pm 2.21 \\
d\end{array}$ & $\begin{array}{l}10.94 \pm \\
0.11 \mathrm{~b}\end{array}$ & $7.40 \pm 0.02 c$ & $1.48: 1$ \\
\hline$F$ & 3.59 & 320.47 & 226.45 & 1529.19 & 525.34 & 7782.66 & 1512.10 & 9108.09 & 8081.34 & 3999.77 \\
\hline$P$ & 0.002 & 0.000 & 0.000 & 0.000 & 0.000 & 0.000 & 0.000 & 0.000 & 0.000 & 0.000 \\
\hline
\end{tabular}

Where applicable, the ratio of $T$. urticae to larval phytoseiids consumed by adult females is given. Values in each column followed by the same letter are not significantly different $(P>0.05)$ when Neoseiulus barkeri fed on $20 \mathrm{~T}$. urticae/phytoseiid larvae are compared to their other four prey combinations

benefits from phytoseiid larvae in the absence of their main prey (EG-prey). Prey conversion rate was low for N. barkeri considering N. californicus as IG-prey to A. swirskii. According to Ahmad et al. (2015), that parameter could be a sign of the ability for population persistence when prey is moving back.

\section{Performance of Amblyseius swirskii (IG-predator) on Neoseiulus californicus/N. barkeri (IG-prey) and Tetranychus urticae (EG-prey)}

Amblyseius swirskii females survived significantly longer time when fed on a mixed diet of T. urticae with $N$. barkeri/N. californicus $(10$ T.u +10 N. barkeri, 10 T.u +10 $N$. californicus, $20 \mathrm{~T} . \mathrm{u}+20 \mathrm{~N}$. californicus), than those fed solely on IG-prey/EG-prey/(20 T. u $+20 \mathrm{~N}$. barkeri $)$ $\left(F_{6,161}=18.03, P=0.0001\right)$. Females of $A$. swirskii fed solely on T. urticae/N. californicus gave a higher fecundity and daily number of eggs than on $N$. barkeri/on a mixture of $T$. urticae and phytoseiid larvae $\left(F_{6,161}=\right.$ 570.77, 452.90, $P=0.0001$ ) (Table 3).

When A. swirskii fed solely on T. urticae/combined prey, a significant difference was observed in its predation rate $\left(F_{6,161}=3799.15, P=0.000\right)$. When $A$. swirskii fed solely on IG-prey, the total and daily rate of predation were significantly higher on $N$. californicus (Table 3). Amblyseius swirskii consumed more $T$. urticae in total than those fed on a mixed diet. Providing of $T$. urticae significantly decreased the predation of IG-prey (Table 3). Amblyseius swirskii consumed significantly a higher number of IG-prey $N$. barkeri/N. californicus than when mixed with T. urticae (case of $20 \mathrm{~T}$. urticae +20 IG-prey) than in (case of $10 \mathrm{~T}$. urticae +10 IG-prey). Amblyseius swirskii consumed up to $1.62,1.79$, and $1.41,1.73 \mathrm{~T}$. urticae for every $1 N$. barkeri and $N$. californicus when fed on both prey sources.

Interesting results presently in the fecundity of $A$. swirskii fed exclusively IG-prey $N$. californicus was similar to those fed EG-prey $T$. urticae. IG-prey might be an equally good or better food source than the EG-prey (thrips) for both A. swirskii and N. cucumeris (Oudemans) (Buitenhuis et al. 2010). In their studies, Guo et al. (2016) indicated that IG-prey A. orientalis (Ehara) appeared to be better food source for the development of A. swirskii than EG-prey Bemisia tabaci Gennadius. They added that $A$. swirskii appears to be a less suitable prey for A. orientalis. In the contrary, Polis et al. (1989) demonstrated that the quality of IG-prey is often lower than the quality of EG-prey. Momen and El-Borolossy (2010) showed that A. swirskii was able to feed and develop on both IG-prey C. negevi and Phytoseius finitimus Ribaga, whereas the latter species failed to develop on other both IG-prey. Research has been done by Pratt et al. (2002) and also Xu and Enkegard (2010) indicated that some factors are responsible for the preference of predatory mites, such as plant architecture, prey stage 
Table 3 Mean ( \pm SE) pre-oviposition, oviposition periods and longevity, mean number ( \pm SE) of total and daily eggs laid per female, total and daily number ( \pm SE) of prey consumed per female for Amblyseius swirskii fed solely on Tetranychus urticae (T.u.) or larval Neoseiulus barkeri (N.b.), Neoseiulus californicus (N.c.), or on a combination of T. urticae and larval phytoseiid

\begin{tabular}{|c|c|c|c|c|c|c|c|c|c|c|}
\hline \multirow{3}{*}{$\begin{array}{l}\text { Prey and } \\
\text { number }\end{array}$} & \multicolumn{3}{|l|}{ Periods } & \multicolumn{2}{|c|}{ Eggs laid per female } & \multicolumn{4}{|c|}{ Consumption rates } & \multirow{3}{*}{$\begin{array}{l}\text { Ratio of } \\
\text { T. u.: } \\
\text { predator } \\
\text { larvae } \\
\text { consumed }\end{array}$} \\
\hline & \multirow{2}{*}{$\begin{array}{l}\text { Pre- } \\
\text { oviposition }\end{array}$} & \multirow[t]{2}{*}{ Oviposition } & \multirow[t]{2}{*}{ Longevity } & \multirow{2}{*}{$\begin{array}{l}\text { Total } \\
\text { eggs }\end{array}$} & \multirow{2}{*}{$\begin{array}{l}\text { Daily } \\
\text { eggs }\end{array}$} & \multicolumn{2}{|c|}{ Total consumption } & \multicolumn{2}{|c|}{ Daily consumption } & \\
\hline & & & & & & T.u. & $\begin{array}{l}\text { Phytoseiid } \\
\text { larvae }\end{array}$ & T.u. & $\begin{array}{l}\text { Phytoseiid } \\
\text { larvae }\end{array}$ & \\
\hline 20T.u. & $\begin{array}{l}1.58 \pm 0.10 \\
a\end{array}$ & $\begin{array}{l}24.33 \pm 0.16 \\
\text { de }\end{array}$ & $\begin{array}{l}28.25 \pm \\
0.19 \mathrm{~cd}\end{array}$ & $\begin{array}{l}26.42 \pm \\
0.20 \mathrm{a}\end{array}$ & $\begin{array}{l}1.09 \pm \\
0.01 \mathrm{a}\end{array}$ & $\begin{array}{l}394.67 \pm \\
3.63 \mathrm{a}\end{array}$ & & $\begin{array}{l}13.98 \pm \\
0.13 a\end{array}$ & & \\
\hline 20 N.b. & $\begin{array}{l}1.67 \pm 0.10 \\
a\end{array}$ & $\begin{array}{l}24.58 \pm \\
0.22 \mathrm{~cd}\end{array}$ & $\begin{array}{l}28.58 \pm \\
0.25 \mathrm{~cd}\end{array}$ & $\begin{array}{l}24.42 \pm \\
0.16 b\end{array}$ & $\begin{array}{l}1.00 \pm \\
0.01 \mathrm{~b}\end{array}$ & & $\begin{array}{l}300.83 \pm 2.65 \\
b\end{array}$ & & $\begin{array}{l}10.53 \pm 0.02 \\
b\end{array}$ & \\
\hline 20 N.c. & $\begin{array}{l}1.75 \pm 0.09 \\
a\end{array}$ & $\begin{array}{l}23.83 \pm 0.17 \\
e\end{array}$ & $\begin{array}{l}28.00 \pm \\
0.19 \mathrm{~d}\end{array}$ & $\begin{array}{l}25.67 \pm \\
0.23 a\end{array}$ & $\begin{array}{l}1.08 \pm \\
0.01 \mathrm{a}\end{array}$ & & $\begin{array}{l}403.33 \pm \\
10.43 \mathrm{a}\end{array}$ & & $14.39 \pm 0.34 \mathrm{a}$ & \\
\hline $\begin{array}{l}10 \text { T.u. }+10 \\
\text { N.b. }\end{array}$ & $\begin{array}{l}1.67 \pm 0.10 \\
a\end{array}$ & $\begin{array}{l}26.17 \pm 0.14 \\
a\end{array}$ & $\begin{array}{l}30.08 \pm \\
0.16 a\end{array}$ & $\begin{array}{l}15.83 \pm \\
0.17 \mathrm{~d}\end{array}$ & $\begin{array}{l}0.61 \pm \\
0.01 \mathrm{~d}\end{array}$ & $\begin{array}{l}184.02 \pm \\
2.08 \mathrm{~d}\end{array}$ & $\begin{array}{l}113.58 \pm 0.93 \\
e\end{array}$ & $\begin{array}{l}6.13 \pm \\
0.09 \mathrm{e}\end{array}$ & $3.78 \pm 0.02 \mathrm{e}$ & $1.62: 1$ \\
\hline $\begin{array}{l}\text { 10T.u. + } 10 \\
\text { N.c. }\end{array}$ & $\begin{array}{l}1.58 \pm 0.10 \\
a\end{array}$ & $\begin{array}{l}26.25 \pm 0.15 \\
a\end{array}$ & $\begin{array}{l}30.25 \pm \\
0.23 a\end{array}$ & $\begin{array}{l}14.58 \pm \\
0.23 e^{-}\end{array}$ & $\begin{array}{l}0.56 \pm \\
0.01 \mathrm{e}\end{array}$ & $\begin{array}{l}197.73 \pm \\
2.45 c\end{array}$ & $\mathrm{e}^{114.54 \pm 1.15}$ & $\begin{array}{l}6.54 \pm \\
0.09 \mathrm{~d}\end{array}$ & $3.79 \pm 0.02 \mathrm{e}$ & $1.73: 1$ \\
\hline $\begin{array}{l}20 \text { T.u. }+20 \\
\text { N.b. }\end{array}$ & $\begin{array}{l}1.67 \pm 0.10 \\
a\end{array}$ & $\begin{array}{l}25.17 \pm 0.17 \\
b c\end{array}$ & $\begin{array}{l}29.08 \pm \\
0.16 b c\end{array}$ & $\begin{array}{l}18.58 \pm \\
0.23 c\end{array}$ & $\begin{array}{l}0.74 \pm \\
0.01 c\end{array}$ & $\begin{array}{l}355.69 \pm \\
3.47 b\end{array}$ & $\begin{array}{l}199.00 \pm 1.76 \\
d\end{array}$ & $\begin{array}{l}12.23 \pm \\
0.09 \mathrm{~b}\end{array}$ & $6.84 \pm 0.03 d$ & $1.79: 1$ \\
\hline $\begin{array}{l}20 \text { T.u. }+20 \\
\text { N.c. }\end{array}$ & $\begin{array}{l}1.58 \pm 0.10 \\
a\end{array}$ & $\begin{array}{l}25.83 \pm 0.17 \\
a b\end{array}$ & $\begin{array}{l}29.75 \pm \\
0.28 \mathrm{ab}\end{array}$ & $\begin{array}{l}18.92 \pm \\
0.18 \mathrm{C}\end{array}$ & $\begin{array}{l}0.73 \pm \\
0.01 c\end{array}$ & $\begin{array}{l}353.31 \pm 3.9 \\
0 \mathrm{~b}\end{array}$ & $\begin{array}{l}250.92 \pm 2.19 \\
c\end{array}$ & $\begin{array}{l}11.88 \pm \\
0.05 c\end{array}$ & $8.44 \pm 0.03 c$ & $1.41: 1$ \\
\hline$F$ & 0.40 & 32.09 & 18.03 & 570.77 & 452.90 & 3799.15 & 1009.22 & 5297.62 & 1332.71 & 3379.11 \\
\hline P & 0.876 & 0.000 & 0.000 & 0.000 & 0.000 & 0.000 & 0.000 & 0.000 & 0.000 & 0.000 \\
\hline
\end{tabular}

Where applicable, the ratio of $T$. urticae to larval phytoseiids consumed by adult females is given. Values in each column followed by the same letter are not significantly different $(P>0.05)$ when Amblyseius swirskii fed on $20 \mathrm{~T}$. urticae/phytoseiid larvae are compared to their other four prey combinations

preference, and interaction between the pest and the predator.

\section{Conclusion}

Base on this study, A. swirskii seems to be a stronger IG predator than both other species because it consumed more larvae of $N$. barkeri and N. californicus and also, laid more eggs on both IG prey. According to this study, A. swirskii, N. barkeri, and N. californicus are IG predators on each other even when T. urticae is present. The results of this study showed that IGP among these 3 phytoseiids is not unidirectional. Potential IG-interaction among these predatory mites may strongly influence the predator efficiency in T. urticae control. Information about the strength and direction of IGP among these predators can be helpful for choosing the best strategy of multiple releases to improve the control of $T$. urticae.

\section{Abbreviations}

IGP: Intraguild predation; IG-predator: Intraguild predator; IG-prey: Intraguild prey; EG-prey: Extra-guild prey

\section{Acknowledgements}

Authors would like to thank the staff of the Acarology Unit, Plant Protection Department National Research Centre.

\section{Authors' contributions}

FM designed and wrote the manuscript. AA performed the experiment and analyzed the data. All authors read and approved the final manuscript.

\section{Funding}

There is no fund.
Availability of data and materials

The datasets used during the current study are available from the corresponding author on reasonable request.

Ethics approval and consent to participate

All applicable international, national, and/or institutional guidelines for the care and use of animals were followed. This article does not contain any studies with human participants or vertebrates performed by any of the authors.

\section{Consent for publication}

Not applicable.

\section{Competing interests}

This study was performed in absence of any competing interests.

Received: 2 September 2020 Accepted: 17 December 2020

Published online: 05 January 2021

\section{References}

Addison JA, Hardman JM, Walde SJ (2000) Pollen availability for predaceous mites on apple: spatial and temporal heterogeneity. Exp Appl Acarol 24:1-18

Ahmad S, Pozzebon A, Duso C (2015) Predation on heterospecific larvae by adult females of Kampimodromus aberrans, Amblyseius andersoni, Typhlodromus pyri and Phytoseius finitimus (Acari: Phytoseiidae). Exp Appl Acarol 67:1-20

Bonde J (1989) Biological studies including population growth parameters of the predatory mite Amblyseius barkeri (Acari: Phytoseiidae) at $25^{\circ} \mathrm{C}$ in the laboratory. Entomophaga 34:275-287

Buitenhuis R, Shipp L, Scott-Dupree C (2010) Intra-guild vs extraguild prey: effect on predator fitness and preference of Amblyseius swirskii (Athias-Henriot) and Neoseiulus cucumeris (Oudemans) (Acari: Phytoseiidae). Bull Entomol Res 100: $167-173$

Farazmand A, Fathipour Y, Kamali K (2015) Intraguild predation among Scolothrips longicornis (Thysanoptera: Thripidae), Neoseiulus californicus, and Typhlodromus bagdasarjani (Acari: Phytoseiidae) under laboratory conditions. Insect Sci 22:263-272 
Guo Y, Lv J, Jiang X, Wang B, Gao E, Xu X (2016) Intraguild predation between Amblyseius swirskii and two native Chinese predatory mites species and their development on intraguild prey. Sci Rep 6:22992

Haghani S, Zahedi-Golpayegani A, Saboori A, Allahyari H (2019) The effect of con/ heterospecific diet on predation, oviposition and longevity of Amblyseius swirskii, Neoseiulus californicus and Phytoseiulus persimilis (Acari: Phytoseiidae). Syst Appl Acarol 24:2240-2252

Hatherly IS, Bale JS, Walters KFA (2005) Intraguild predation and feeding preferences in three species of phytoseiid mite used for biological control. Exp Appl Acarol 37:43-55

Huang H, Xu XN, Lv JL, Li GT, Wang ED, Gao YL (2013) Impact of proteins and saccharides on mass production of Tyrophagus putrescentiae (Acari: Acaridae) and its predator Neoseiulus barkeri (Acari: Phytoseiidae). Biocontrol Sci Tech 23:1231-1244

Janssen A, Montserrat M, HilleRisLambers R, de Ross AM, Pallini A, Sabelis MW (2006) Intraguild predation usually does not disrupt biological control. In: Brodeur J, Boivin $\mathrm{G}$ (eds) Trophic and guild interactions in biological control. Springer, Netherlands, pp 21-44

Lucas É (2005) Intraguild predation among aphidophagaous predators. Eur J Entomol 102:351-364

Maleknia B, Fathipour Y, Soufbaf M (2016) Intraguild predation among three phytoseiid species, Neoseiulus barkeri, Phytoseiulus persimilis and Amblyseius swirskii. Syst Appl Acarol 21:417-426

McMurtry JA, Moraes GJ, Sourassou NF (2013) Revision of the lifestyles of phytoseiid mites (Acari: Phytoseiidae) and implications for biological control strategies. Syst Appl Acarol 18:297-320

Messelink G, van Steenpaal SEF, Ramakers MJ (2006) Evaluation of phytoseiid predators for control of western flower thrips on greenhouse cucumber. Biocontrol 51:753-768

Meszaros A, Tixier MS, Cheval B, Barbar Z, Kreiter S (2007) Cannibalism and intraguild predation in Typhlodromus exhilaratus and T. phialatus (Acari: Phytoseiidae) under laboratory conditions. Exp Appl Acarol 33:37-43

Momen FM (2009) Potential of three species of predatory phytoseiid mites as biological control agents of the peach silver mite, Aculus fockeui (Acari: Phytoseiidae and Eriophyidae). Acta Phytopathol Entomol Hung 44:151-158

Momen FM (2010) Intra-and interspecific predation by Neoseiulus barkeri and Typhlodromus negevi (Acari: Phytoseiidae) on different life stages: predation rates and effects on reproduction and juvenile development. Acarina 18:8188

Momen FM, Abdel-Khalek A (2009a) Juvenile survival and development of Typhlodromips swirskii, Euseius scutalis and Typhlodromus athiasae (Acari: Phytoseiidae) feeding on con-and heterospecific immatures. Acta Phytopathol Entomol Hung 44:167-176

Momen FM, Abdel-Khalek A (2009b) Cannibalism and intraguild predation in the phytoseiid mites Typhlodromus swirskii, Euseius scutalis and Typhlodromus athiasae (Acari: Phytoseiidae). Acarina 17:223-229

Momen FM, El-Borolossy ME (1999) Suitability of the citrus brown mite, Eutetranychus orientalis as prey for nine species of phytoseiid mites (Acari: Tetranychidae: Phytoseiidae). Acarologia 40:19-30

Momen FM, El-Borolossy ME (2010) Juvenile survival and development in three phytoseiid species (Acari: Phytoseiidae) feeding on con- and heterospecific immatures. Acta Phytopathol Entomol Hung 45:349-357

Montserrat M, Magalhaes S, Sabelis MW, de Roos AM, Janssen A (2012) Invasion success in communities with reciprocal intraguild predation depends on the stage structure of the resident population. Oikos 12:67-76

Polis GA, Myers CA, Holt RD (1989) The ecology and evolution of intraguild predation: potential competitors that eat each other. Annu Rev Ecol Syst 20: 297-330

Pratt PD, Rosetta R, Croft BA (2002) Plant related factors influence the effectiveness of Neoseiulus fallacis (Acari: Phytoseiidae), a biological control agent of spider mites on landscape ornamental plants. J Econ Entomol 95: 1135-1141

Ramakers PMJ, Van Lieburg MJ (1982) Start of commercial production and introduction of Amblyseius mckenziei Sch and Pr. (Acarina: Phytoseiidae) for the control of Thrips tabaci Lind. (Thysanoptera: Thripidae) in glasshouses. Med Fac Landbouww Rijksuniv Gen 47:541-545

Riahi E, Fathipour Y, Talebi AA, Mehrabadi M (2017) Natural diets versus factitious prey: comparative effects on development, fecundity and life table of Amblyseius swirskii (Acari: Phytoseiidae). Syst Appl Acarol 22:711-723
Schausberger P (1999) Predation preference of Typhlodromus pyri and Kampimodromus aberrans (Acari: Phytoseiidae) when offered con- and heterospecific immature life stages. Exp Appl Acarol 23:389-398

Schausberger P (2003) Cannibalism among phytoseiid mites: a review. Exp App Acarol 29:173-191

Walzer A, Paulus HF, Schausberger P (2004) Ontogenetic shifts in intraguild predation on thrips by phytoseiid mites: the relevance of body size and diet specialization. Bull Entomol Res 94:577-584

Walzer A, Schausberger P (1999) Predation preferences and discrimination between con- and heterospecific prey by the phytoseiid mites Phytoseiulus persimilis and Neoseiulus californicus. Biocontrol 43:469-478

Walzer A, Schausberger P (2013) Integration of multiple cues allows threatsensitive anti-intraguild predator responses in predatory mites. Behaviour 150:115-132

Xu X, Enkegard A (2010) Prey preference of the predatory mite, Amblyseius swirskii between first instar western flower thrips Frankliniella occidentalis and nymphs of the twospotted spider mite Tetranychus urticae. J Insect Sci 10:1-

\section{Publisher's Note}

Springer Nature remains neutral with regard to jurisdictional claims in published maps and institutional affiliations.

\section{Submit your manuscript to a SpringerOpen ${ }^{\circ}$ journal and benefit from:}

- Convenient online submission

- Rigorous peer review

- Open access: articles freely available online

High visibility within the field

- Retaining the copyright to your article

Submit your next manuscript at $\boldsymbol{\nabla}$ springeropen.com 